\title{
Competing in the graduate labour market: Student perspectives on (not) participating in extra-curricular activities
}

\author{
Paul Greenbank ${ }^{1}$ \\ greenbap@edgehill.ac.uk
}

${ }^{1}$ Edge Hill University

\begin{abstract}
In order to be able to compete in an increasingly competitive graduate labour market students need to develop their 'personal capital'. Participation in a range of relevant extracurricular activities (ECAs) is a key element to the development of personal capital. This paper carried out in-depth interviews with undergraduates in the first and final years of their studies in order to understand the factors influencing their level of participation in ECAs. The research found that participation in ECAs was generally limited (with little change occurring during the three years of their degree), particularly in relation to year-long work placements, volunteering and sporting and cultural activities. Students often engaged in part-time working, but this was for financial reasons, with few students regarding part-time working as a way of developing their employability. The students underlying values, especially their present-time orientation, and the desire to enjoy a particular student life-style, acted as barriers to engaging in the type of ECAs that would help them to develop their personal capital. This paper suggests that higher education institutions may be able to motivate students to participate in ECAs by encouraging them to be future-orientated, less risk averse and willing to adopt a more strategic (i.e. 'player') approach to developing their personal capital. The paper proposes that this can be achieved by encouraging students to write about their future possible selves and asking them to undertake research into the different career options open to them.
\end{abstract}

Keywords: employability, personal capital, extra-curricular activities, graduate labour market, future possible selves, risk

\section{Introduction}

The rise of mass higher education (HE) in many countries of the world, including the UK, has resulted in increased competition for graduate jobs (defined as professional or high level managerial positions by the UK's Destinations of Leavers from Higher Education Institutions (DLHE) Survey). ${ }^{1}$ It must, however, be appreciated - as Brown and Hesketh (2004) and Roulin and Bangerter (2013) have pointed out - that there is considerable variation in the quality of graduate jobs, in terms of pay and other conditions of employment. Brown and Hesketh (2004, argue that mass HE has attracted many more contestants but [this] has not been accompanied by a commensurate expansion in the number of high-quality professional and managerial jobs (p.12). Moreover, as a result of the global economic downturn the competition for jobs has intensified in recent years so that: 
[n]ever before in the field of higher education have so many graduates, from so many universities, competed with each other for so few jobs. Never before have the rewards for those who succeed been so great, nor the risks for those who don't been so costly (Redmond, 2010, p.3).

The evidence suggests (see for example Blasko, 2002; Chia, 2005; Tchibozo, 2007; Hinchliffe \& Jolly, 2011; CBI/EDI, 2011) that in order to be able to compete in the graduate labour market, especially for the 'better' jobs, students need to develop and package what Brown and Hesketh (2004, p.34) refer to as 'personal capital' in a way that is attractive to employers. Personal capital comprises of 'soft currencies' and 'hard currencies' and can be used by students to construct a narrative of their productive potential to perspective employers (see Figure 1 below).

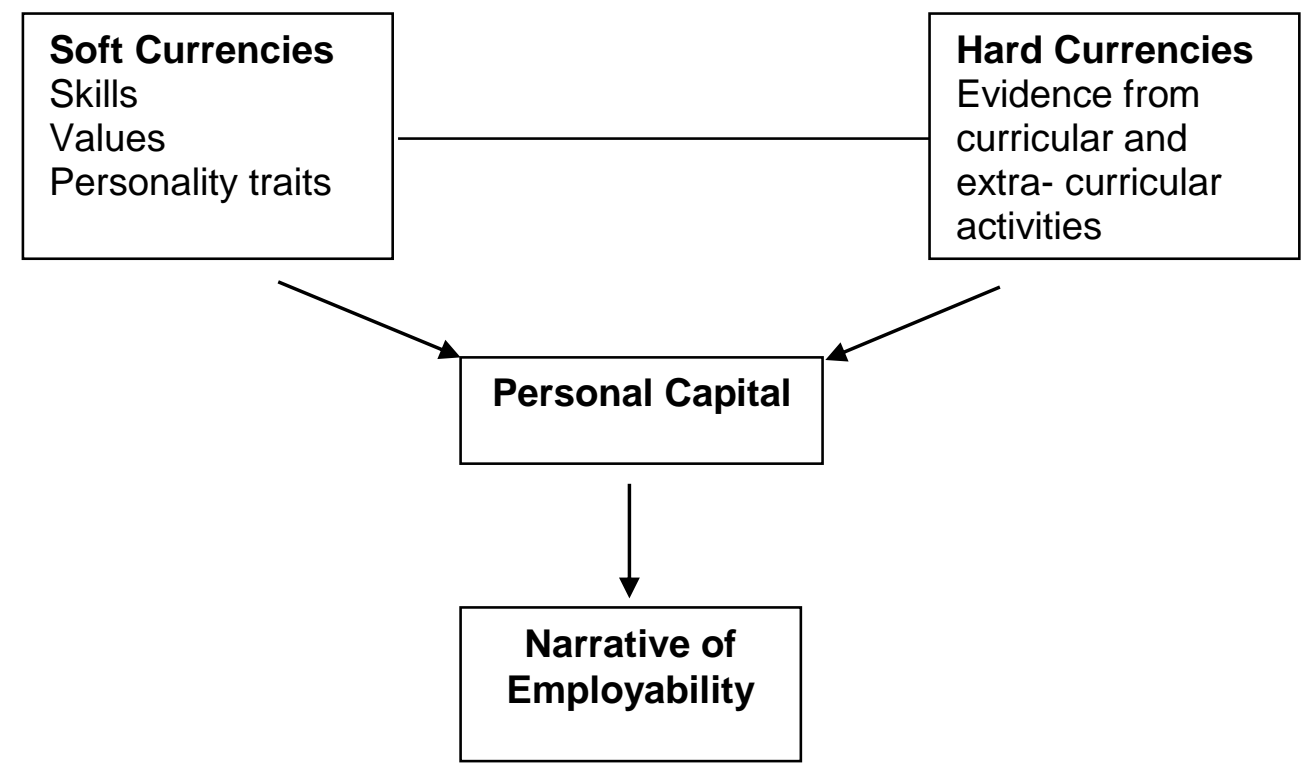

Figure 1: Conceptualising the Construction of Personal Capital

Soft currencies are the skills, values and personality traits that graduate employers are seeking. According to Maher and Graves (2008, pp.16-17) - who used five key research studies on what employers are looking for to draw up a list of skills and attributes - these include skills (such as problem-solving, team working, communication and selfmanagement) and values and personality traits (such as commitment, flexibility, selfconfidence and the ability to work under pressure).

Students also need to provide evidence - what Brown and Hesketh (2004) refer to as 'hard currencies' - to demonstrate they possess the skills, values and personality traits that employers are looking for. These hard currencies consist of credentials, such as the student's degree and other qualifications gained at school, college and elsewhere. Credentials are used as a heuristic device, enabling an employer to simplify their decisionmaking by making assumptions about the attributes graduates are likely to possess if they have certain qualifications. Therefore, employers may ask for certain minimum grades from colleges and universities (Tomlinson, 2008; Redmond, 2010). However, employers also want students to provide concrete evidence, through their participation in both curricular and extra-curricular activities (ECAs), of the soft currencies they possess (Brown \& Hesketh, 2004; Hinchliffe \& Jolly, 2011). As a result, students need to be able to provide examples of how their studies and ECAs demonstrate they possess particular skills, values and 
personality traits; and they need to be able to present this in a 'narrative' that demonstrates their productive potential. As Brown and Hesketh (2004) state:

The value employers attach to both hard and soft currencies depends on how they are packaged as a narrative of employability. This involves being able to present one's experiences, character, and accomplishments in ways that conform to the competence profiles scrutinized by employers (p.36).

Graduate employers are taking greater account of student participation in ECAs because mass HE means there are significantly more job applicants with similar credentials - and organisations have to find ways of differentiating between them (Brown \& Hesketh, 2004; Tomlinson, 2008). This is not to say that credentials are unimportant, but these need to be supplemented by appropriate forms of ECA (Tomlinson, 2008). Indeed, the evidence from quantitative studies indicates a positive correlation exists between engagement in ECAs and successful labour market outcomes (Blasko, 2002; Chia, 2005; Tchibozo, 2007). It is, however, not only the level of participation that is significant to graduate recruiters, but also the relevance of the skills and attributes developed and utilised in ECAs (Blasko, 2002; Tchibozo 2007; Hinchliffe \& Jolly, 2009). The evidence suggests that employers favour graduates who have engaged in a wide range of activities (Hinchliffe \& Jolly, 2009).

There have been relatively few studies into student engagement in ECAs in higher education (Lehmann, 2012; Roulin \& Bangerter, 2013). This paper concentrates on the extent to which students participate in ECAs in order to develop their personal capital - and the rationale they provide for their level of engagement (or non-engagement) in such activities. The paper will begin by discussing the methodological approach adopted in this study. Next, the extent to which the students in this study participated in ECAs will be examined. The factors influencing the students' engagement in ECAs will then be analysed. Finally, the implications of the findings for higher education institutions (HEls) will be discussed.

\section{Research design and characteristics of the sample}

This paper focuses on a sample of full-time accounting, business and management and computing undergraduates in a Business School at a 'new' university in England. ${ }^{2}$ The fulltime undergraduates in the Business School completed a questionnaire and were asked if they would be willing to be interviewed. A cross-section of students (in terms of age, gender and degree studied), who agreed to participate, were selected for interview. These students were interviewed at the beginning of their degree and then re-interviewed in their final year, just weeks before they graduated. This made it possible to identify any changes in attitude the students had towards ECAs during the period they were studying for their degree. The research was ethically approved by the Business School under the aegis of the university's research ethics framework.

The interviews utilised a semi-structured format that enabled important topics to be explored in depth. There is precedence for such an approach. For example, Tomlinson's (2008) study involved semi-structured interviews with 53 final year students. Similarly, Lehmann's (2012) longitudinal study examined the factors influencing participation in ECAs by students from working class backgrounds using interviews.

All the interviews for this study were recorded and later transcribed. The data was analysed and the key factors influencing the students' participation in ECAs were identified using matrices and cognitive maps (see Easterby-Smith, Thorpe, \& Jackson, 2012; Thomas, 2013). Thirty-four students were interviewed in their first year and 21 of these re-interviewed in their third year. The decline in the number of interviews arose because some students had withdrawn from their degree programmes (usually because they had failed modules); whilst others (a small minority) did not wish to be interviewed a second time. 
This study concentrates on the 21 undergraduates who were interviewed in both their first and third year of study. The characteristics of these students in terms of age, gender and degree programme was broadly representative of the type of students in the Business School. As can be seen from Table 1 the majority of the students were 20 years of age or under when they started their degrees. The sample had slightly more female students than male students. Although three students failed to complete their degree within the 'normal' three-year period of study, the remainder of the students in this study were relatively high academic performers with over 80 per cent of them achieving either an upper-second class honours degree or a first class honours degree. As such, it is recognised that this aspect of the sample is not representative of the Business School. However, it is worth noting that despite these good degree classifications, only five of these students had secured a graduate job six months after graduation (see Table 1 below).

\section{Table 1: Characteristics of the Sample}

\begin{tabular}{|c|c|c|c|c|}
\hline Code $^{1}$ & Age $^{2}$ & Gender & Degree classification $^{3}$ & Career destination $^{4}$ \\
\hline $\mathrm{A} 1$ & 18 & Male & Referred & Not applicable \\
\hline A3 & 19 & Female & $1^{\mathrm{st}}$ & Non-graduate job \\
\hline A6 & 18 & Male & 2.2 & Graduate job \\
\hline B2 & 19 & Female & 2.2 & Non-graduate job \\
\hline B4 & 20 & Female & 2.2 & Not known \\
\hline B5 & 19 & Female & 2.1 & Unemployed \\
\hline B6 & 19 & Male & 2.1 & Non-graduate job \\
\hline B8 & 19 & Female & 2.1 & Graduate job \\
\hline B9 & 40 & Female & Referred & Not applicable \\
\hline B12 & 18 & Female & 2.1 & Graduate job \\
\hline B15 & 20 & Male & $1^{\text {st }}$ & Not known \\
\hline B16 & 18 & Male & 2.1 & Unemployed \\
\hline B17 & 18 & Female & 2.1 & Non-graduate job \\
\hline B20 & 22 & Female & 2.1 & Non-graduate job \\
\hline B21 & 18 & Female & 2.1 & Non-graduate job \\
\hline B22 & 18 & Female & 2.1 & Not known \\
\hline C1 & 24 & Male & $1^{\text {st }}$ & Graduate job \\
\hline $\mathrm{C} 2$ & 24 & Male & $1^{\text {st }}$ & Not known \\
\hline C3 & 20 & Female & Referred & Not applicable \\
\hline $\mathrm{C} 4$ & 21 & Male & 2.1 & Travelling \\
\hline $\mathrm{C} 5$ & 29 & Male & $1^{\text {st }}$ & Graduate job \\
\hline \multicolumn{5}{|l|}{ Notes } \\
\hline \multicolumn{5}{|c|}{$\begin{array}{l}\text { 1. A = Accounting student, } B=\text { Business \& Management student, } C=\text { Computing student. Only students who were interviewed } \\
\text { in their first and third years are included in Table } 2 \text { which is why some numbers are missing. }\end{array}$} \\
\hline \multicolumn{5}{|c|}{ 2. This is the age of the student at the beginning of their degree. } \\
\hline \multicolumn{5}{|c|}{$\begin{array}{l}\text { 3. The UK system divides honours degrees into four classifications: first class ( }\left(1^{\text {st }}\right) \text {, upper-second class }(2.1) \text {, lower-second } \\
\text { class }(2.2) \text { and third class }\left(3^{\text {rd }} \text { ). The students who are referred have not completed their degrees because they still have to }\right. \\
\text { pass one or more of their modules. }\end{array}$} \\
\hline \multicolumn{5}{|c|}{$\begin{array}{l}\text { 4. This refers to the occupational status of students six months after graduation. Students were contacted by telephone and } \\
\text { they were classified using the Standard Occupational Classification (SOC) framework. In this occupations are defined as } \\
\text { graduate if they are professional or managerial and normally require a degree. See: } \text { http://www.ons.gov.uk/ons/guide- } \\
\text { method/classifications/current-standard-classifications/soc2010/soc2010-volume-1-structure-and-descriptions-of-unit- } \\
\text { groups/index.htm/\#4 (accessed 10/2/12) }\end{array}$} \\
\hline
\end{tabular}

Greenbank, P. (2014). Competing in the graduate labour market: Student perspectives on (not) participating in extra-curricular activities. Journal of Teaching and Learning for Graduate Employability, 5(1), 63-79. 


\section{Student engagement in extra-curricular activities}

For this research a wide definition of what constitutes ECAs was adopted. The definition used incorporated all activities undertaken outside the formal university curriculum and included part-time employment, volunteering, sporting and cultural activities and engagement in work placements that are optional and additional to a student's degree.

HEls have recognised the need to encourage student engagement in ECAs. As a result, there has been an increasing trend towards offering awards recognising student participation in ECAs (see CBI/NUS, 2001; Pegg, Waldock, Hendy-lsaac, \& Lawton, 2012; QAA, 2013). For example, the QAA (2013), in a survey involving 69 HEls in the UK, found that 75 per cent of institutions offered some form of award scheme for student engagement in ECAs, with 84 per cent of these awards being initiated in the last five years.

At the time the research for this paper was undertaken the university that was the subject of this study did not have awards for student participation in ECAs, but they did advertise and promote opportunities to engage in various types of ECA. Table 2 (below) summarises the ECAs students in this study were involved in during their time at university.

Table 2: Involvement in Extra-curricular Activities

\begin{tabular}{|c|c|c|c|c|c|c|c|}
\hline & & $\begin{array}{l}\text { Part-time } \\
\text { employment }\end{array}$ & & Volunteering & & $\begin{array}{l}\text { ing/cultural } \\
\text { ctivities }\end{array}$ & $\begin{array}{l}\text { Sandwich } \\
\text { placements }\end{array}$ \\
\hline A1 & $\checkmark$ & Bar/office work & $x$ & & $x$ & & $x$ \\
\hline A3 & $\checkmark$ & Bar work & $x$ & & $x$ & & $x$ \\
\hline A6 & $\checkmark$ & Sales assistant & $x$ & & $\checkmark$ & Gym & $x$ \\
\hline B2 & $\checkmark$ & Carer & $\checkmark$ & St John Ambulance & $x$ & & $x$ \\
\hline B4 & $x$ & & $x$ & & $x$ & & $x$ \\
\hline B5 & $x$ & & $\checkmark$ & Charity fund raising & $x$ & & $x$ \\
\hline B6 & $\checkmark$ & Sales assistant & $x$ & & $x$ & & $x$ \\
\hline B8 & $\checkmark$ & Sales assistant & $x$ & & $x$ & & $x$ \\
\hline B9 & $\checkmark$ & Sales assistant & $x$ & & $x$ & & $x$ \\
\hline B12 & $\checkmark$ & $\begin{array}{l}\text { Sales assistant } \\
\text { Receptionist }\end{array}$ & $x$ & & $\checkmark$ & $\begin{array}{l}\text { Dancing } \\
\text { Gym }\end{array}$ & $x$ \\
\hline B15 & $\checkmark$ & $\begin{array}{l}\text { Sales assistant } \\
\text { Team leader } \\
\text { Project co- } \\
\text { ordinator }\end{array}$ & $x$ & & $\checkmark$ & Gym & $x$ \\
\hline B16 & $x$ & & $x$ & & $\checkmark$ & Music & $x$ \\
\hline B17 & $\checkmark$ & $\begin{array}{l}\text { Sales } \\
\text { assistant }\end{array}$ & $\checkmark$ & Charity work & $\checkmark$ & Football & $x$ \\
\hline B20 & $\checkmark$ & $\begin{array}{l}\text { Sales } \\
\text { assistant }\end{array}$ & $\checkmark$ & Charity fund raising & $\checkmark$ & $\begin{array}{l}\text { Jogging } \\
\text { Swimming } \\
\text { Music }\end{array}$ & $x$ \\
\hline B21 & $x$ & & $\checkmark$ & $\begin{array}{l}\text { Police } \\
\text { (administrative } \\
\text { support) }\end{array}$ & $\checkmark$ & $\begin{array}{l}\text { Music } \\
\text { Gym }\end{array}$ & $x$ \\
\hline B22 & $\checkmark$ & $\begin{array}{l}\text { Sales assistant } \\
\text { Team leader }\end{array}$ & $x$ & & $x$ & & $x$ \\
\hline C1 & $\checkmark$ & Bar work & $x$ & & $\checkmark$ & $\begin{array}{l}\text { Football } \\
\text { Music }\end{array}$ & $x$ \\
\hline $\mathrm{C} 2$ & $\checkmark$ & Bar work & $x$ & & $\checkmark$ & Football & $x$ \\
\hline
\end{tabular}

Greenbank, P. (2014). Competing in the graduate labour market: Student perspectives on (not) participating in extra-curricular activities. Journal of Teaching and Learning for Graduate Employability, 5(1), 63-79. 


\begin{tabular}{|l|c|l|c|l|c|l|c|}
\hline C3 & $\checkmark$ & Sales assistant & $x$ & & $x$ & & $x$ \\
\hline C4 & $\checkmark$ & Sales assistant & $\checkmark$ & $\begin{array}{l}\text { Police (Special } \\
\text { constable) } \\
\text { Camp America }\end{array}$ & $\checkmark$ & $\begin{array}{l}\text { Rock } \\
\text { climbing } \\
\text { Kiting }\end{array}$ & $x$ \\
\hline C5 & $\checkmark$ & $\begin{array}{l}\text { Website } \\
\text { organiser }\end{array}$ & $x$ & & $\checkmark$ & $\begin{array}{l}\text { Photo- } \\
\text { graphy }\end{array}$ & $x$ \\
\hline
\end{tabular}

\section{Part-time working}

As can be seen from Table 2, all but four students were engaged in part-time working (for at least some of their time at university). This is not surprising given the extent of part-time working amongst students in higher education (see Curtis \& Williams, 2002; Curtis \& Shani, 2002; Bradley, 2006; Richardson, Gbadamosi \& Evans, 2009; Robotham, 2012). The students indicated that they were working, not because they needed to (in order to cover essential living costs or because they wished to avoid accumulating debt), but because they wanted to be able to enjoy an active social life and maintain a particular (but not necessarily excessive) consumer life-style (see Hodgson \& Spours, 2001; Brooks, 2006; Richardson et al., 2009; Robotham, 2013 for similar findings). For example, in Robotham's (2013) study students were working part-time in order to be able to have an active social life, run a car and purchase items such satellite television. The students in this study made similar comments. This is not to deny that some students - for instance, the students in Moreau and Leathwood's (2006) study - may face financial hardship and need to work in order to stay at university, but this did not appear to be the case for the students in this study.

It is also important to note that a number of students gave up their part-time jobs in their second or third year of study. These students said they did this because they were focused on obtaining a good degree. As C2 (who was in his early twenties) said:

Some of the younger ones come for more of a laugh and a giggle whereas l've done all that ... Getting a good degree is more, you know, important to me. It's what I'm here for.

Similarly, the students who did not work at all during their degree emphasised their desire to concentrate on their studies and obtain a good degree classification. This is reflected in B4's comments:

I want to concentrate on university, Therefore I don't want to work as it will take up my time. I don't want to spend a lot of time doing a job and not getting a good degree.

\section{Volunteering}

Students can also develop their personal capital by engaging in unpaid ECAs such as volunteering. Table 2 demonstrates that only six of the 21 students in this study engaged in volunteering during their time at university. Some of these activities involved a long-term commitment, such as working as a volunteer for St. John Ambulance ${ }^{3}$ or working as a Special Constable for the Police; whilst other volunteering activities involved a short-term commitment such as charity fund-raising.

What is important, is that despite being encouraged to volunteer in order to improve their personal capital - through careers input and modules such as Personal Development Planning (PDP) ${ }^{4}$ - the students were not increasing their level of volunteering during their time at university. Indeed, the students involved in volunteering (especially those engaged in long-term volunteering), were often continuing something they were participating in prior to coming to university - and usually because of the influence of their parents. For example, B17 was engaged in charitable work organised by her mother and B2 was involved with the 
St. John Ambulance with her parents. Roulin and Bangerter (2013) also point out that the students in their study were often continuing with ECAs they had begun as children.

When the students involved in volunteering were questioned about why they were participating in such activities they emphasised interest and enjoyment rather than a desire to develop their employability. For example, B2 who was involved with St John Ambulance said:

I suppose it might help when I go for a job, but I don't do it for that reason. I've always done it. I mean since a young age with my mum and dad. And I enjoy it (laughs) and have friends and that there so I keep doing it. I enjoy it and that, it's a laugh and that.

\section{Sporting and cultural activities}

Table 2 also indicates that over half the students were engaged in sporting or cultural activities. The interviews revealed that the sporting and cultural activities the students were participating in mainly involved weight training in the gym, often to pursue a particular body image rather than to keep fit; playing non-competitive football with friends; and playing a musical instrument (usually a guitar) for fun. The students would, therefore, generally find it difficult to use their participation in sporting and cultural activities to demonstrate they possessed the type of skills (e.g. communication, team working, problem-solving, etc.) and values and personality traits (e.g. commitment, confidence, etc.) that graduate employers are looking for (see Maher \& Graves, 2008; Redmond, 2010).

\section{Placements}

The undergraduate programmes in the Business School all offered students the opportunity to apply for a year-long sandwich placement between Years 2 and 3 of their degrees. Yet as Table 2 illustrates, no student in this sample undertook such a placement. This is significant because the evidence suggests that work experience, especially those involving lengthy placements, are highly valued by prospective employers and make a valuable contribution to improving graduate employability (Blasko, 2002; BIS, 2011; Lowden, Hall, Elliot \& Lewin, 2011; CBI/EDI, 2011; Wilson, 2012; Pegg et al., 2012). For example, Blasko (2002) found work placements had a beneficial impact on employment outcomes (in terms of obtaining graduate jobs, higher salaries and greater job satisfaction), particularly those placements lasting more than eight months.

In their first year interviews more than half the students indicated that they were interested in undertaking a year-long placement. The decline in interest may, in part, be due to the accounting and business and management students being given the opportunity to undertake a short-term (4 week) placement as part of their degree programme. However, the students said the most important reason for not going on a year-long placement was a desire to remain with their own cohort of students, particularly their friends. In addition, many students feared losing their part-time jobs. (These issues are discussed in more detail in the next section of the paper).

\section{Barriers to the development of personal capital}

It can be seen, that despite opportunities to engage in ECAs (including opportunities promoted by the university) the students in this study did not make extensive use of ECAs in order to develop their personal capital. The study found that there were three key factors influencing the extent to which students participated in ECAs. Each of these will be discussed below. 


\section{Lack of a future-orientation}

Individuals exhibiting a future-orientation plan for the long-term and engage in activities that involve making sacrifices in order to reap benefits in the future (Zimbardo \& Boyd, 1999; Fried, Grant, Levi, Hadani \& Slowik, 2007). The interviews indicate that the vast majority of students in this study were not thinking of the future - and even those who were, did so infrequently and in little depth. This lack of a future-orientation is significant because it means students focus on the present and activities that will provide them with satisfaction immediately or in the very near future. For most students this necessitates combining study with part-time work in order to maintain a particular 'student life style'.

As well as providing an income to fund their life-style, part-time work provides an opportunity for students to develop the type of skills and attributes that graduate employers are seeking (Bowlby, Evans \& Roche, 2000; Curtis \& Shani, 2002; Manthei \& Gilmore, 2005; Robotham, 2012). Davies (2000) also suggests that having experience in more than one part-time job helps to develop a greater range of skills; whilst Cranmer (2006) emphasises the importance of students obtaining work experience relevant to the career path they wish to pursue. The students in this study were aware of the benefits of part-time work through careers input and modules such as PDP. As a result, many students indicated in their first year interviews that they would try and obtain different part-time jobs to the ones they currently had. However, the third year interviews revealed that the vast majority of the students had remained in the same part-time job throughout their degree. This was because their jobs met their immediate needs. For example, B6 had worked for a large retailer as a customer adviser since he was 17 years-old. In his first year interview he said he did not want to work in retail and would find a part-time job that was more relevant to his career aspirations. Yet when he was reinterviewed in his final year of study he was still in the same job. B6 justified this with the following comment:

I suppose I am just a bit comfortable with having a regular income and working somewhere I know and have got used to. I know the job and the people and everything.

A number of students gave similar rationales for remaining in their current jobs. They also frequently emphasised that their part-time job had to be compatible with the demands of student life, with factors such as hours, shift patterns and the physical and psychological burden of the work they were doing, being mentioned by interviewees. For example, A6, did not want to take on a supervisory role in his part-time job, even though this would enhance his personal capital (especially as he was aiming to obtain a job in management), because he wanted to be able to avoid stress and concentrate on his studies:

Last year they said do you want to be a supervisor? But I said like it'll give me more responsibility, but it's just more pressure for me you know, opening times, making sure I've got the keys, sorting out rotas and stuff. I don't NEED [capital letters are used when the interviewee emphasises a word] to do that, I just need to come into work, do what I need to do and just get out.

The fact that students like A6 make their academic work a priority might of course be seen as a rational decision given evidence to suggest that engaging in ECAs can have a negative effect on student learning, particularly where students are engaged in excessive amounts of part-time working (Barke et al., 2000; Curtis \& Shani, 2002; Curtis \& Williams, 2002; Metcalf, 2003; Humphrey, 2006). However, as Table 2 illustrates, it is generally not part-time working that is being sacrificed, but other non-paid (and arguably more important) forms of ECA. As discussed above, this appears to occur because most students focus on their immediate futures and they need their part-time job to maintain their student life-style.

This also means that any thought of substituting unpaid for paid ECAs was something students were, in the main, unwilling to contemplate. As already mentioned, the risk of losing 
their part-time jobs was a significant barrier to engaging in a year-long placement. For example, B17 admitted she did not want to risk her part-time job by going on a work placement because, It's hard to find one round here because of all the students. Similarly, B6 had concerns about the effect of a work placement on his part-time job:

I thought about doing internships and stuff like that. One of my friends did an internship in London. It was with [names a bank]. He was telling me about that and it sounded really good and I was thinking maybe that's something I'll do. But I thought, if I'm doing that, would that clash with what I was doing there? [In his part-time job].

B6 was asked about engaging in non-paid ECAs, such as volunteering, in order to enhance his employability, but he said he did not have time for such things. However, B6 admitted that during the summer months, when he would have the time, he worked 40 hours a week in his job for, as he put it, purely financial reasons.

Other students also blamed their non-engagement with unpaid ECAs on a lack of time. But when it was pointed out to them that they could participate in such activities during the summer months, when they were not at university, they agreed this was a possibility. However, many of the students still felt they needed the summer to recuperate from the intensity of university life. As A6 said:

I suppose I could [engage in ECAs] in the summer. Yes, I know what you're saying. I think the thing is after all your university work, the eight months or whatever it is you are here, I think you DO just want a break, you know what I mean? I think you just don't want to make time over the summer. If you were going to try and find time NOW, because you're busy, you just don't have the time. But when you've got the time you don't want to find it; I don't want to do it now, I'm tired. I know like you have a massive break but like you need it.

B21 also acknowledged that she could have engaged in ECAs over the summer months, but she did not because I need a rest after all the assignments and exams and that. It takes so much out of you. She also said:

the summer is the time I CAN do nothing. I've got until I'm sixty-five to work. I go to the gym, have a night out, do whatever I want.

\section{Purist orientation}

Brown and Hesketh (2004) differentiate between 'players' and 'purists' and argue that they should be conceptualised as two extreme types of orientation along a continuum. Players are students who understand what employers are looking for and are willing to engage in ECAs with the expressed aim of enhancing their personal capital in order to meet the requirements of graduate recruiters. In contrast, purists prefer to present the 'real' or authentic self to potential employers and would be unwilling to engage in ECAs with the sole purpose of enhancing their personal capital. The implication is that students with a player orientation are likely to perform better in the graduate labour market.

When they were presented with the player-purist categorisation in their first year interviews students expressing a player orientation (about a quarter of those interviewed) often did so in pragmatic terms. For example C4 said he would operate as a player because that's the way of the world. In contrast, purists (nearly half the sample) said they would not engage in ECAs with the sole purpose of enhancing their personal capital. As C5 said, I would only really be interested in doing things that I enjoy. Similarly, B17 said, I think for it to be volunteering without pay it has to be something that REALLY grabs you.

The students often stressed that they were morally opposed to packaging themselves in a way that was not authentic; and some were uncomfortable with the idea of competing in the 
labour market through the development of personal capital. For example, B5 believed that engaging in activities in order to enhance personal capital was like lying on your $\mathrm{CV}$. Similarly, B2 said, I'd feel uncomfortable making myself look good for others. It's like I would be putting someone else out of a job who really wants it and me TAKING it off them.

Brown and Hesketh (2004) classified about one-third of the students as operating with a blend of both player and purist approaches. Roulin and Bangerter $(2013, p .43)$ also found students adopting what they refer to as a 'mixed strategy', with students sometimes adopting a player orientation and at other times a purist-orientation. The difference is that Roulin and Bangerter (2013) found most students adopted a mixed strategy. In this study about a quarter of the students interviewed in their first year had, not a mixed or blended approach, but a more ambiguous orientation. They said they wanted to be players, but they admitted they did not have the motivation to engage in the type of ECAs that employers valued. These students said that they had other more pressing objectives relating to the fact that they had a present, rather than a future, time orientation.

When the students were re-interviewed in their final year very few students had shifted along the continuum to be more player orientated and the students who indicated a desire to be player orientated had not acted upon this. This is reflected in the lack of engagement in career enhancing ECAs (see Table 2). In the third year interviews there was, however, some regret amongst students that they had not engaged in more ECAs. They were aware that they had disadvantaged themselves positionally vis-à-vis other students in the graduate labour market. As A3 said:

I wish I HAD hobbies and interests, I DO because it would make my CV look better. And just like the social aspects as well I think, I think it would have been good. But mainly like it means others will be going for jobs and they will look better than me even if they aren't because they have done things to make them look good and that.

\section{Risk aversity}

The students in this study tended to be risk averse. This can be seen as problematic because graduate employers are often seeking graduates who, to use the words of Hinchliffe and Jolly (2009, p.20), are prepared to step outside the familiar and the comfortable. Students were, however, often unwilling to do this because of what Zeelenberg (1999) refers to as 'anticipatory regret' and the fact that people are often heavily influenced by a desire to avoid the cost of making a bad decision (Diamond, Vorley, Roberts \& Jones, 2012). This is exemplified by the comments of B8, who in her first year interview indicated a reluctance to engage in ECAs in case it proved to be something that graduate recruiters did not value. If this proved to be the case it would mean she had invested time (which represents a cost) in something without benefit. As she said, I could do something and it may not even be relevant and then waste all that time. B8 subsequently had the opportunity to undertake a year-long placement with a large company, but she did not attend the interview because she was uncertain of the benefits of undertaking a placement; and she also feared that after taking a year out she would have to join a cohort of students on her degree that she did not know. This was something B8 regretted when she was reinterviewed in her third year:

I wished l'd gone now, but I never went because I thought when I get back to uni I won't know anyone. I just bottled it really (laughs). I had the opportunity but I thought I wouldn't know anyone when I got back.

The fact that the students would be with a different cohort of students when they returned from a year-long placement was a key factor in many of them not taking this option up. As another student (B17) commented, You come back and you're in a whole different year without your friends. Everything you're familiar with goes. As already discussed, the 
students were also concerned about the risk of losing their part-time job if they went on a placement.

Risk aversity is also linked to the students' lack of confidence. Tomlinson (2007) found that a number of students in his study were apprehensive about engaging in ECAs because they did not believe they had the cultural capital to enable them do this effectively. Similarly, in this study some of the students commented on how they were aware of opportunities to volunteer from the university's website, but they did not feel they had the personality or skills to engage in such activities. The emotions students feel are well represented by the comments of B4 who said:

I don't know if I could do this [volunteering]. I'm not that kind of person. You know, would I be good at it sort of thing? It would be good if you could do it with your friends or with your lecturers, kind of thing or something. It's scary (laughs).

The students also commented on not wanting to take a risk with their degree. For example, C1 was reluctant to engage in ECAs in case it jeopardised his aim of achieving a first class honours degree. Similarly, A6 feared that participating in ECAs would have a detrimental effect on his degree and 'without your degree you're not going to get a good job anyway'.

\section{Discussion and implications}

This study has demonstrated that the students were not making extensive use of ECAs to develop their personal capital. The factors influencing the extent to which the students in this study engaged in ECAs can be conceptualised as values along a continuum (see Figure 2 below), with values to the left of the continuum acting as barriers to participating in ECAs and values to the right facilitating engagement in ECAs.

\begin{tabular}{|ll|}
\hline Barriers & Facilitators \\
\hline Present orientation $\longmapsto$ & Future-orientation \\
Risk aversity & Risk taking \\
'Purist' orientation $\longmapsto$ & 'Player' orientation \\
\hline
\end{tabular}

\section{Figure 2: Factors Influencing Student Engagement in Extra-curricular Activities}

If this university wants these students to participate in ECAs there is, therefore, a need to shift the students to the right of the continuum so they become more future-orientated; have a greater willingness to take risks; and begin to act more like 'players'. There may, however, be concerns about attempting to promote such changes. It may, for example, be argued (as many of the students in this study did) that they do not want to be future-orientated, as this is likely to be their one opportunity to be a full-time student - and as such, their only chance to enjoy a 'student-life style'. On the other hand, in the second interviews which took place just before they graduated, many students indicated regret at not having engaged with ECAs. This was not only because they believed this had adversely affected their employability, but also because they felt that they may have enjoyed engaging in certain ECAs. This is noteworthy, as students in the first year interviews often regarded ECAs (especially unpaid ECAs) negatively because they could not see any immediate benefits to be gained from participating in them. However, as Gilovich and Medvec (1995) have found, whilst the failure 
to act on something (i.e. 'the road not taken') may not produce regret in the short-term, it often does in the longer-term.

It might also be argued that the university should not be encouraging students to take risks. This paper is, however, suggesting that the students' decision-making is biased by their risk aversity - and linked to this - a desire to avoid uncertainty. This risk aversity arises because the students in this study tended to focus on costs rather than benefits; and the short-term rather than the longer-term. For example, the students often did not want to participate in unpaid ECAs because of the 'cost' in time and their inability to recognise the short-term benefits associated with engaging in ECAs (for example the chance to make new friends and be exposed to new, and potentially enjoyable, experiences). This is exacerbated by the fact that the longer-term benefits are uncertain, whereas the short-term benefits of using this time to participate in other activities, such as paid employment, are more immediate and tangible. As Bazerman (2006, p.65) states the vividness of the present is a very powerful influence. This paper is, therefore, not arguing that students should become risk takers, only that they become less risk averse. This can be achieved by encouraging students to focus on both the costs and benefits of engaging in different ECAs and asking them to consider the long-term, as well of the short-term, costs and benefits when making decisions.

There might also be objections to promoting a player orientation amongst students. It is suggested that encouraging students to engage in ECAs, because it will enhance their employability, may be seen as encouraging inauthenticity (Greenbank, 2013). There will, however, be students operating as 'players' (see Brown \& Hesketh, 2004; Roulin \& Bangerter, 2013) and the students in this study will have to compete against them for jobs. Moreover, if students are engaged in ECAs they are not committed to, this may be seen as unfair to the organisations where these ECAs are undertaken, especially if it involves charities. On the other hand, if students engage in ECAs for personal gain, this does not mean that there will be no third-party benefit to their participation. Furthermore, a student may engage in a particular ECA for what might be seen as inappropriate reasons, but it may result in positive changes to their personality and values.

It is clearly not possible to say whether other students (for example those studying different subjects and/or attending other HEls) would exhibit the same type of behaviour, and be influenced by similar values, to the students in this study. There is, therefore, a need to be cautious about making generalisations from this research. With this proviso in place, it is nevertheless useful to consider how the reluctance of students to engage in ECAs can be addressed.

This research found that the tendency for students to adopt a present, rather than a future, time orientation was the most important factor influencing student participation in ECAs. This is because a present time orientation not only prevents students considering the longer-term benefits of engaging in ECAs, but it also (as this paper has demonstrated) contributes to the creation of other barriers to participating in ECAs, such as risk aversity and a reluctance to adopt a player orientation. One way of helping students to shift to a future-orientation is to encourage them to think and write about their 'future possible selves', both frequently and in depth.

Leondari (2007) defines future possible selves as representing [T]hose selves that a person could become, would like to become, or is afraid of becoming ... They encompass both hoped-for and feared images of the self (p.8). Similarly, Plimmer and Schmidt (2007, p.64) state that, [P]ossible selves can be positive (hopes) or negative (fears). For students, therefore, it could be the negative image of being unemployed or having to continue to work in their part-time jobs after graduation; and the positive image of pursuing a career that offers extrinsic rewards (e.g. a good salary) and intrinsic rewards (e.g. job satisfaction) that 
provides the motivation they need to participate in ECAs. These images of the future can be instrumental in motivating behaviour and shaping aspirations, especially if they are considered frequently and in-depth (Markus \& Nurius, 1986; Segal, DeMeis, wood \& Smith, 2001; Rossiter, 2007). As Rossiter (2007, p.90) contends:

[P]eople are more likely to take action ... if they have a well developed possible self ... If an individual really cannot envision herself or himself doing something, it is unlikely that behaviour will be directed towards that end.

However, Stevenson and Clegg (2011) point out that students can only include possible selves that they know about and can envisage. It is, therefore, important for students to be aware of the various career opportunities available. This can be achieved through careers talks which identify different possibilities and by lecturers discussing employment with their students, although on their own these are liable to lead to a relatively limited selection of career options. As such, students should be encouraged to research possible career routes for themselves. The added advantage of this is that the students will be able to identify careers that match their personal aspirations (both extrinsic and intrinsic) and their strengths (in terms of skills, values and personalities traits).

Research indicates that individuals do not tend to reflect, in any depth, on the values underpinning their behaviour (Maio \& Olson, 1998; Bardi \& Goodwin, 2011). By encouraging students to consider their future possible selves, and by asking them to research different career options, they will be required to systematically and rigorously reflect on the values influencing their attitude to participating in ECAs. As this paper has pointed out risk aversion tends to arise because students often focus on the short-term costs involved in participating in ECAs. Encouraging students to both reflect on their future possible selves and to undertake research into the advantages and disadvantages of different career options, will help move them away from a risk averse bias that acts as a barrier to engaging in ECAs. The combination of a future-orientation and a debiased approach to risk taking should also help students become more player orientated and therefore willing to engage in ECAs.

As part of an action research project the author of this paper has already introduced interventions that have influenced student attitudes towards ECAs (see for example Greenbank, 2010, 2011). These interventions include encouraging students to collect information about different career options. The author has also been working with students who are writing about their future possible selves (hoped-for and feared). This exercise has been well received by students who have indicated that it has made them think more seriously about engaging in ECAs. However, this feedback has, to date, only been collected informally through class feedback and there has been no attempt to monitor student participation in ECAs following this exercise. There is, therefore, a need to evaluate more rigorously the effectiveness of asking students to write about their future possible selves, which will include monitoring how they subsequently perform in the graduate labour market. 


\section{Notes}

1. See 'Sources of Employment Data' on: https://unistats.direct.gov.uk/find-out-more/about-thedata/ [accessed 31/7/14].

2. Institutions that obtained university status after 1992 are referred to as 'new' universities. In contrast, universities that were formed prior to 1992 are referred to as 'old' universities.

3. St. John Ambulance is a charity that supplies first aid and training in health and safety.

4. For the PDP module students reflect on their learning and achievements by completing progress files which are then used to plan their personal, educational and career development (see Ward and Watts, 2009). 


\section{References}

Barke, M., Braidford, P., Houston, M., Hunt, A., Lincoln, I., Morphet, C., Stone, I. \& Walker, A. (2000). Students in the labour market: Nature, extent and implications of term-time employment among University of Northumbria undergraduates. Norwich: DfEE Research Report No. 215.

Bardi, A. \& Goodwin, R. (2011). The dual route to value change: Individual processes and cultural moderators. Journal of Cross-Cultural Psychology, 42(2), 271-287.

Bazerman, M. (2006). Judgement in managerial decision making. (6 $6^{\text {th }}$ ed.). New York: John Wiley \& Sons.

BIS. (2011). Supporting graduate employability: HEI practice in other countries, BIS Research Paper No. 40. London: Department for Business, Innovation and Skills.

Blasko, Z. (2002). Key skills: The graduate perspective. Higher Education Digest, Centre for Higher Education Research and Information. Milton Keynes: The Open University.

Bowlby, S., Evan, S.L. \& Roche, C. (2000). Racialised gendering, locality and young people's employment opportunities. London: ESRC.

Bradley, G. (2006). Work participation and academic performance: A test of alternative propositions. Journal of Education and Work, 19(5), 481-501.

Brooks, R. (2006). Learning and work in the lives of young adults. International Journal of Lifelong Education, 25(3), 271-289.

Brown, P. \& Hesketh, A. (2004). The mismanagement of talent: Employability and jobs in the knowledge economy. Oxford: Oxford University Press.

CBI/EDI. (2011). Building for growth: Business priorities for education and skills. Education and skills survey 2011, Confederation of British Industry/Educational Development International. Accessed 24/5/14. http://www.cbi.org.uk/media/1051530/cbi edi education skills survey 2011.pdf

CBI/NUS (2011). Working towards your future: Making the most of your time in higher education, London: Confederation of British Industry/National Union of Students.

Chia, Y. M. (2005). Job offers of multi-national accounting firms: The effects of emotional intelligence, extra-curricular activities, and academic performance. Accounting Education: An International Journal, 14(1), 75-93.

Cranmer, S. (2006). Enhancing graduate employability: Best intentions and mixed outcomes. Studies in Higher Education, 31(2), 169-184.

Curtis, S. \& Shani, N. (2002). The effect of taking paid employment during term-time on students' academic studies. Journal of Further and Higher Education, 26(2), 129-138.

Curtis, S. \& Williams, J. (2002). The reluctant workforce: Undergraduates' part-time Employment. Education and Training, 44(1), 5-10.

Davies, L. (2000). Why kick the "L" out of "LEarning"? The development of students' employability skills through part-time working. Education and Training, 42(8), 436-444.

Diamond, A., Vorley, T., Roberts, J. \& Jones, S. (2012). Behavioural approaches to understanding student choice. York: The Higher Education Academy.

Easterby-Smith, M., Thorpe, R. \& Jackson, P. (2012). Management Research. (4 ${ }^{\text {th }}$ ed.). London: Sage.

Fried, Y., Grant, A.M., Levi, A.S., Hadani, M. \& Slowik, L.H. (2007). Job design in temporal context: A career dynamics perspective. Journal of Organizational Behavior, 28(7), 911927. 
Gilovich, T. \& Medvec, V.H. (1995). The experience of regret: What, when and why. Psychological Review, 102(2), 379-395.

Greenbank, P. (2010). Initiating change in career decision-making: An action research approach. Manchester: Research Study for the Higher Education Careers Service Unit (HECSU). Accessed 24/5/14

http://www.hecsu.ac.uk/assets/assets/documents/initiating change in career decision making.pdf

Greenbank, P. (2011). Improving the process of career decision making: An action research project. Education and Training, 53(4), 252-266.

Greenbank, P. (2013). Implementing an action research project: A case study in making decisions and managing challenges. International Journal of Research and Method in Education, 36(2), 145-161.

Hinchliffe, G. \& Jolly. A. (2009). Employer concepts of graduate employability. York: The Higher Education Academy, Subject Centre for Education (ESCalate).

Hinchliffe, G. W. \& Jolly, A. (2011). Graduate identity and employability. British Educational Research Journal, 37(4), 563-584.

Hodgson, A. \&. Spours, K. (2001). Part-time work and full-time education in the UK: The emergence of a curriculum and policy issue. Journal of Education and Work, 14(3), 373388.

Humphrey, R. (2006). Pulling structured inequality into higher education: The impact of parttime working on English university students. Higher Education Quarterly, 60(3), 270-286.

Lehmann, W. (2012). Extra-credential experiences and social closure: Working class students at university. British Educational Research Journal, 38(2), 203-218.

Leondari, A. (2007). Future time perspective, possible selves, and academic achievement. New Directions for Adult and Continuing Education, 114, 17-26.

Lowden, K., Hall, S., Elliot, D. \& Lewin, J. (2011). Employers' perceptions of the employability skills of new graduates. London: Edge Foundation.

Maher, A. \& Graves, S. (2008). Graduate employability: Can higher education deliver? Newbury: Threshold Press.

Manthei, R.J. \& Gilmore, A. (2005). The effect of paid employment on university students' lives. Education and Training, 47(3), 202-215.

Maio, G.R. \& Olson, J.M. (1998). Values as truisms: Evidence and implications. Journal of Personality and Social Psychology, 74(2), 294-311.

Markus, H. \& Nurius, P. (1986). Possible selves. American Psychologist, 41(9), 954-969.

Metcalf, H. (2003). Increasing inequality in higher education: The role of term-time working. Oxford Review of Education, 29(3), 315-329.

Moreau, M-P. \&. Leathwood, C. (2006). Balancing paid work and studies: Working-class students in higher education. Studies in Higher Education, 31(1) 23-42.

Pegg, A., Waldock, J., Hendy-Isaac, S. \& Lawton, R. (2012). Pedagogy for employability. York: The Higher Education Academy.

Plimmer, G. \& Schmidt, A. (2007). Possible selves and career transition: It's who you want to be, not what you want to be. New Directions for Adult and Continuing Education, 114, 61-74.

QAA (2013). Recognising achievement beyond the curriculum. Gloucester: The Quality Assurance Agency for Higher Education. 
Redmond, P. (2010). The graduate jobs formula: How to land your dream career. Richmond: Trotman.

Richardson, M., Gbadamosi, G. \& Evans, C. (2009). Funding full-time study through parttime work. Journal of Education and Work, 22(4), 319-334.

Robotham, D. (2012). Student part-time employment: Characteristics and consequences. Education and Training, 54(1), 65-75.

Robotham, D. (2013). Students' perspectives on term-time employment: An exploratory qualitative study. Journal of Further and Higher Education, 37(3), 431-442.

Rossiter, M. (2007. Possible selves in adult education. New Directions for Adult and Continuing Education, 114, 87-94.

Roulin, N. \&. Bangerter, A. (2013). Students' use of extra-curricular activities for positional advantage in competitive job markets. Journal of Education and Work, 26(1), 21--47.

Segal, H.G., DeMeis, D.K., Wood, G.A. \& Smith, H.L. (2001). Assessing future possible selves by gender and socioeconomic status using the anticipated life history measure. Journal of Personality, 69(1), 57-87.

Stevenson, J. \& Clegg, S. (2011). Possible selves: Students orientating themselves towards the future through extracurricular activity. British Educational Research Journal, 37(2), 231-246.

Tchibozo, G. (2007). Extra-curricular activity and the transition from higher education to work: A survey of graduates in the United Kingdom. Higher Education Quarterly, 61(1), 37-56.

Thomas, G. (2013). How to do your research project ( $2^{\text {nd }}$ ed.). London: Sage.

Tomlinson, M. (2007). Graduate employability and student attitudes and orientations to the labour market. Journal of Education and Work, 20(4), 285-304.

Tomlinson, M. (2008). 'The degree is not enough': Students' perceptions of the role of higher education credentials for graduate work and employability. British Journal of Sociology of Education, 29(1), 49-61.

Ward, R. \& Watts, J.G. (2009). Personal development planning and employability. York: Higher Education Academy.

Wilson, T. (2012). A review of business-university collaboration. London: Department for Business, Innovation and Skills.

Zeelenberg, M. (1999). Anticipated regret, expected feedback and behavioral decisionmaking. Journal of Behavioral Decision Making, 12(2), 93-106.

Zimbardo, P.G \& J.N. Boyd, J.N. (1999). Putting time in perspective: A valid, reliable individual-differences metric. Journal of Personality and Social Psychology, 77, 1271-88 